\title{
perifèria
}

Número 18(2), diciembre 2013

http://revistes.uab.cat/periferia

\section{Fum als ulls: etnografia i arqueologia a la Terra del Foc}

\author{
Jordi Estévez (Dept. Prehistòria, UAB) ${ }^{1}$ i Assumpció Vila (Dept. \\ d'Arqueologia i Antropologia IMF-CSIC, Barcelona)
}

\section{Resumen}

Los grupos de gente canoera del sur de Tierra del Fuego entraron en contacto con los navegantes europeos que a partir de la expedición de Magallanes intentaron circumnavegar el extremo sur de América rumbo al Pacífico. Las descripciones que de esos grupos se hicieron a partir de entonces fueron cambiando a medida que fue cambiando la propia sociedad europea. Sin embargo, gracias a esas informaciones, teniendo en cuenta esos cambios, y contrastando con resultados arqueológicos es posible hacernos una idea objetiva de cómo organizaron sus estrategias de sobrevivencia y reproducción social.

\begin{abstract}
Canoe people groups of southern Tierra del Fuego contacted European sailors, who since the Magellan's expedition attempted to circumnavigate the southern end of America to the Pacific. The picture we got on these groups was changing as the European society itself was changing. But considering the biases in the succesive sources and contrasting this information with archaeological data, it is possible to get an objective idea of how these people organized their survival strategies and social reproduction.
\end{abstract}

\section{Introducció}

Des de 1986 i durant mes de 20 anys vàrem realitzar successius projectes de recerca a la Isla Grande de Tierra del Fuego (extrem sud sud-americà) coordinats amb d'altres equips de recerca argentins, bàsicament del Centre Austral de Investigaciones Científicas (CADIC-CONICET) a Ushuaia.

El nostre objectiu primordial va ser desenvolupar mitjançant l'Etnoarqueologia una metodologia arqueològica que ens permetés aconseguir una interpretació global de les comunitats prehistòriques que subsistiren de la cacera, la pesca i la recol·lecció (Estévez i Vila, 1995; Piana, et al. 1992; Piana i Vila, 1993).

\footnotetext{
${ }^{1}$ Enviar correspondencia a: Jordi Estévez: jordi.estevez@uab.es
} 


\section{perifèria}

Número 18(2), diciembre 2013

http://revistes.uab.cat/periferia

El plantejament fou recuperar primer la imatge general del mode de vida indígena (fonts escrites, fotografies, materials dels museus etnogràfics) per a contrastar-la després amb els resultats obtinguts en excavacions arqueològiques de diferents jaciments recents de la mateixa gent descrita, a fi de comprovar l'adequació del mètode arqueològic i trobar la manera de superar les seves mancances.

La Isla Grande de Tierra del Fuego és un lloc privilegiat per aquest tipus de recerca: compta amb molta documentació etnogràfica, una gran riquesa i visibilitat de jaciments arqueològics i un ecosistema relativament poc alterat.

Vàrem completar la recollida i posteriorment analitzar tota la informació històrica i etnogràfica existent, per després estudiar (amb enfocament arqueològic) els materials dipositats en els museus etnogràfics dels grups anomenats pels etnògrafs yàmana, alakaluf i selknam. Aquests foren els grups que visqueren fins a començament del segle XX de la cacera, la pesca i la recol-lecció a I'Illa Grande de Tierra del Fuego.

En el desenvolupament dels Projectes s'han fet excavacions arqueològiques en cinc assentaments quotidians, en dues inhumacions i en dues cabanes cerimonials de dues de les agrupacions indígenes fueguines: yàmana - la litoral meridional- i selknam -la septentrional que no utilitzava canoes.

Els resultats dels projectes es troben en una sèrie de monografies (Treballs d'Etnoarqueologia) editades pel CSIC, en diferents publicacions periòdiques i capítols de llibre i de forma resumida i gràfica en el DVD "Investigaciones en el fin del mundo: la gente canoera de Tierra del Fuego" produït per I'ICE de la UAB (Vila, e.a. 2006). Aquest DVD inclou els tres vídeos realitzats durant els projectes: Etnoarqueología en el Canal Beagle (1992), Humo en los ojos (1996) y Desenterrando relaciones (2006), i també una vintena de presentacions on els i les investigadores del projecte exposen les seves particulars aportacions en els diferents temes inclosos en les investigacions etnoarqueològiques dutes a terme a la Terra del Foc. En el segon vídeo, Humo en los ojos, revisem les informacions escrites al llarg del segles. Aquestes informacions i descripcions estan subjectes als diferents contextos personals i socials de qui escriu i nosaltres plantegem el paper que hi pot jugar I'arqueologia eliminant subjectivitats. En el present treball recollim 


\section{perifèria}

Número 18(2), diciembre 2013

http://revistes.uab.cat/periferia

resumidament i actualitzem aquest temàtica que creiem encara vigent pel que fa a la relació entre els diferents tipus de fonts sobre una mateixa societat.

\section{El canvi de perspectiva dels informants europeus.}

El domini estratègic del canal de Magallanes per part dels espanyols a partir del segle XVI va empènyer els navegants rivals, anglesos i holandesos, a cercar un pas alternatiu cap el Pacífic vorejant el cap d'Hornos.

Foren però els germans espanyols García de Nodal els que varen contactar per primera vegada amb els indígenes de la punta més oriental de Terra del Foc.

Al segle XVII durant l'exploració de I'holandès Jaques l'Hermite comandant de la flota de Nassau, es produeix una primera topada violenta amb indígenes canoers del sud, els quals maten a 17 tripulants.

Aquest fet sumat a la perillositat de la navegació contribuí a crear una imatge de la zona $\mathrm{i}$ dels seus habitants gens acollidora. Ben al contrari, els indígenes eren descrits com a com gent estranya i paradigma de la ferocitat, sense govern, religió, ni pudor, caníbals comparables als animals.

En els anys successius el tràfic de vaixells de pirates, comerciants i exploradors (1712 Frezier, 1721 Roggeveen, 1766 Bougainville, 1769, 1774 i 1775 James Cook, 1785 Antonio de Cordova...) va ser intensiu. Abans de la fi del segle va començar l'explotació anglesa i nord-americana de llops marins i cetacis a gran escala, i fins i tot s'instal·laren en les illes circumdants factories de processat. S'intensificaren així els contactes amb la gent indígena canoera.

La II·lustració, a finals del segle XVIII, canvià aquella primera imatge i els yàmana es presentaven ara com un poble petit i pobre condemnat a viure en una naturalesa que els era desfavorable i que per això havia anat degenerant, perdent les seves idees per sobreviure finalment en un estat $d$ 'indigència. Aquesta perspectiva encara va ser compartida pel jove Charles Darwin, que va passar per allà al 1833 en el que fou el segon viatge del capità Fitz Roy (Vila, 2013). 


\section{perifèria}

Número 18(2), diciembre 2013

http://revistes.uab.cat/periferia

En la segona meitat del segle XIX els anglesos havien pres el domini del mar i la iniciativa de les colonitzacions, que començaven amb les Missions anglicanes arreu. Si bé els primers assajos a Terra del Foc (el 1850 i 1859) foren un fracàs, el 1869 es va instal-lar de manera definitiva la South American Mission en una badia al canal Beagle, en el que és avui la ciutat d'Ushuaia. El missioner Thomas Bridges i la seva família (Anne Varder i els seus fills i filles) varen conviure a partir de llavors amb els nadius, aprenent el seu idioma i registrant en els seus diaris i cartes les seves observacions sobre els diferents aspectes de la vida de la gent que anomenaren yaghan (Bridges, 1933).

L'interès científic que en aquell moment desperten els pobles aborígens i la cada cop mes gran acceptació de I'Evolució fan que aquestes societats es comencin a considerar com a representants d'un estadi molt primitiu de la Humanitat, com a fòssils socials vivents.

La Mission Scientifique du Cap Horn, una expedició francesa amb objectius d'observació astronòmica, recull durant un any, 1882, descripcions dels costums $\mathrm{i}$ de les característiques biològiques de la gent que vivia al voltant de la Badia Orange on tenien el camp-base. I en fa moltes fotografies (Hyades i Deniker, 1891).

Ja a començaments del segle XX els missioners $\mathrm{i}$ etnògrafs, dins el corrent de l'anomenat particularisme històric i per tal de cercar contradiccions amb les teories evolucionistes, intenten remarcar per una banda el caràcter primitiu dels costums i de la seva aparença i per altra les característiques "evolucionades" de la seves creences i "espiritualitat". Pretenen donar una explicació històrica considerant el seu primitivisme com la prova de pertànyer a l'estrat més antic del poblament d'Amèrica i alhora representant la forma de viure humana més primitiva. Haurien estat arraconats i aïllats per la pressió de pobles més moderns, tot i que haurien aconseguit adaptar-se a les condicions adverses del territori.

A principis del segle $X X$ el capellà-etnògraf austríac Martin Gusinde recull en diverses visites a la zona tota la informació disponible sobre els grups fueguins i participa en les que seran les darreres cerimònies col-lectives d'aquests grups, alguna preparada especialment per a ell. Publicarà totes aquestes informacions en 


\section{perifèria}

Número 18(2), diciembre 2013

http://revistes.uab.cat/periferia

una important col-lecció de diversos volums (Gusinde, 1937). Però ja aleshores les malalties importades, els canvis forçats dels costums per part dels missioners, les accions dels caçadors de llops i balenes i dels primers colons, juntament amb la integració a l'economia i a la societat dels blancs havia desintegrat i anihilat la forma de vida tradicional (Vila i Estévez, 2002).

En definitiva, al llarg dels 300 anys i escaig des dels primers contactes, la imatge de la gent canoera de Terra del Foc va anar canviant, com un reflex dels canvis en la ideologia predominant a Europa i a Nord-Amèrica (Piana, 1984).

\section{La imatge resultant}

La confrontació entre les diferents fonts d'informació (Orquera i Piana, 1999), la seva contextualització i finalment una contrastació amb el registre arqueològic permetria construir una imatge menys esbiaixada d'aquelles societats i del procés històric que les va generar.

Un llenguatge, una aparença física general diferent, però sobre tot el fet d'utilitzar les canoes per als seus desplaçaments, va permetre als etnògrafs distingir els habitants de les costes meridionals d'altres agrupacions ètniques que s'havien establert a la Terra del Foc. Dins d'aquella agrupació "canoera" existien, però, cinc dialectes diferents i la freqüència de relacions amb les altres agrupacions a l'oest $i$ al nord era variable però fluida.

La gent canoera s'havia organitzat per sobreviure a base dels recursos del litoral de les costes del canal Beagle $\mathrm{i}$ de les illes més meridionals, fins a cap d'Hornos. El greix dels cetacis i dels llops marins els proveïa de calories, i el flux d'aquests animals que procedia de les zones de reproducció a les illes exteriors de difícil accés amb les canoes, els assegurava la continuïtat. Peixos, mol-luscs i aus litorals eren abundants arreu i proporcionaven un aliment de manteniment bàsic. Aquests aliments els complementaven puntualment amb la cacera de guanacs i la recol-lecció d'alguns vegetals i fongs. Les canoes els permetien canviar sovint i fàcilment de lloc no sobre explotant així els bancs de musclos ni altres recursos fixos. Amb les canoes podien també accedir a una amplia varietat de recursos, en 


\section{perifèria}

Número 18(2), diciembre 2013

http://revistes.uab.cat/periferia

l'explotació dels quals s'havien especialitzat amb una tecnologia "senzilla" i eficaç, que incloïa llances, arpons, arcs i fletxes, fones, trampes de llaços, tridents, arrencadors de mol·luscs, salabrets, esquers i línies de pesca...

Les petites cabanes (d'uns $3 \mathrm{~m}$ de diàmetre) fetes amb branques i impermeabilitzades amb herba i pells, que podien construir molt ràpidament i reocupar de manera repetida durant alguns anys, juntament amb l'ús permanent del foc, els permetien sobreviure en les condicions climàtiques fredes pròpies d'aquestes illes.

La sostenibilitat de les seves estratègies organitzatives queda palesa pels mes de 6000 anys que portaven vivint dels recursos del litoral de les illes de l'arxipèlag.

L'evident ajustament entre la producció d'aliments (és a dir l'explotació de recursos amb la seva tecnologia) i la reproducció de persones aconseguida històricament al llarg dels mil·lennis d'experiència acumulada d'èxits i fracassos (Estévez i Vila, 2013) es mantenia amb alts i baixos mitjançant una estricta i exitosa organització social.

L' organització social per a l' aprofitament òptim d'aquests recursos es recolzava, en l'època documentada etnogràficament, en una estricta divisió social/sexual del treball. Aquesta divisió obligava d'una banda a una dependència/convivència quotidianes i d'altra facilitava una diferent valoració d'homes i dones i les seves aportacions al grup. La dissimetria a favor dels homes i la possibilitat de normativitzar la sexualitat reproductiva (de les dones com a element clau en la reproducció) assegurava regular la reproducció del grup.

L'aprenentatge separat per sexes des de la infantesa mantenia aquesta organització. La cerimònia col-lectiva del "Ciexaus" la reforçava periòdicament. En ella joves d'ambdós sexes eren instruïts intensivament durant dies en allò que s'esperava d'ells i elles en la societat adulta.

Els petits grups bàsics (dona(es), home, filles i fills i sovint adultes o adults consanguinis) es formaven a partir de la unió d'una dona i un home que construïen una canoa i se separaven, per norma, de la resta del grup inicial. Aquestes unitats eren pràcticament autosuficients a nivell de la subsistència. 


\section{perifèria}

Número 18(2), diciembre 2013

http://revistes.uab.cat/periferia

Era I'home qui en principi triava i proposava ajuntar-se amb una dona negociant a traves dels seus parents masculins, generalment amb el pare de la dona. Només I'home podia decidir separar-se o afegir una altra dona al grup. La dona en canvi només podia separar-se si els maltractaments eren prou evidents i els seus parents masculins decidien emportar-se-la. En cas de que es quedés vídua, tenia I'obligació d'anar amb el seu cunyat.

Era sempre la dona qui havia de tenir cura de la mainada, estar disposada a preparar i donar menjar a qualsevol del grup o convidat, a tenir el foc encès continuadament...

Aquesta desigualtat en l'ordre social no era equilibrat amb el de les activitats econòmiques de subsistència, en les que la dona havia d'invertir mes temps de treball que I'home. Aquesta desigualtat era reforçada també mitjançant la cerimònia del "Kina". En aquesta només hi participaven els homes però estava dirigida a atemorir les dones contribuint al manteniment d'aquest ordre social. Els homes es pintaven el cos i feien servir unes màscares d'escorça que, a l'ensems de gestos i crits nocturns, els feien aparèixer com a personatges que espantaven les dones.

Aquestes cerimònies es realitzaven quan hi havia un esdeveniment especial, com el verament d'una balena que permetia reunir un grup més gran i romandre en el mateix lloc durant més temps.

Per dur-les a terme es construïen cabanes especials, més grans que les habituals. Era una ocasió que permetia la circulació d'informació i de gent, establir relacions entre els diferents grups i així s'asseguraven les relacions de reproducció mes enllà de les petites unitats bàsiques.

No hi havia cap diferència social vertical. En aquest sentit el sistema funcionava sense l'existència d'un col-lectiu de gent gran que dirigís res. Només existia la figura del yekamush, una mena de curador espiritual que gairebé sempre era un home gran, amb certa influència, però que no tenia poder real ni tampoc medecines.

Faules morals, contes i llegendes que s'explicaven en el dia a dia eren també importants per al manteniment de l'ordre social i l'ensinistrament. 


\section{perifèria}

Número 18(2), diciembre 2013

http://revistes.uab.cat/periferia

\section{Conclusions}

Podem dir que desprès de mil-lennis d'aprenentatge al llarg dels quals en el registre arqueològic s'aprecien reajustaments, oscil/lacions, hiatus i canvis sobtats menors que no modifiquen però l'estructura general de les estratègies d'explotació dels recursos animals, havien aconseguit una certa estabilitat i sostenibilitat del seu sistema. Aconseguien no sobre explotar el medi, i mantenir el control extern de la reproducció del recurs crític, els musclos, al mateix temps que produïen les condicions socials per regular també la reproducció.

En la pràctica volia dir mobilitat constant en les seves canoes i unes relacions asimètriques entre homes i dones. Elles, imprescindibles i clares gestores de la reproducció, en ser desvalorades a nivell productiu, podien ser controlades i així aconseguir una regulació que possibilitava una estabilitat demogràfica, o si mes no reduir la taxa de creixement a curt termini. Les cerimònies, I'educació diferencial per sexe, les llegendes morals, etc ajudaven en aquests controls i en el seu compliment.

El registre arqueològic permet revisar algunes imprecisions en les descripcions $\mathrm{i}$ explicacions històriques i etnogràfiques, donant als grups i la seva organització el protagonisme en el seu procés històric. La gent canoera de Terra del Foc tenia un sistema especialitzat en l'explotació d'un ampli espectre dels recursos més abundants, ubics i previsibles. El seu sistema no era la conseqüència d'una degeneració, ni d'un arraconament, sinó la història d'un èxit per la seva sostenibilitat.

Tot i així, després del desembarcament dels europeus, en poc menys d'un segle la seva forma de vida quedà estroncada de forma irreversible. Les malalties, desnutrició, desarrelament i violències de diferent tipus es varen conjugar contra un vell sistema d'autocontrol de la població. Així, de les prop de 3000 persones que es varen comptabilitzar el 1836, la meitat va morir en una epidèmia el 1864 . Vint anys després havia mort un terç mes de sobrevivents. D'aquests, la meitat morí en un sol any. I el 1907 la Missió anglicana va tancar per manca de nadius. 


\section{perifèria}

Número 18(2), diciembre 2013

http://revistes.uab.cat/periferia

\section{Bibliografia}

Bridges, T. 1987 (1933). Yamana-English dictionary. Ushuaia: Zagier y Urruty Publicaciones.

Estévez, J. y Vila, A. (1995). "Etnoarqueología: el nombre de la cosa". Dins: Estévez, J. i Vila, A (coords.) Encuentros en los conchales fueguinos. Treballs d'Etnoarqueologia, 1, Bellaterra: CSIC. /UAB, pp. 17-23.

Estévez, J. y Vila, A. (1998). "Tierra del Fuego, lugar de encuentros" Revista de Arqueología Americana, no 15, pp.187-219.

Estévez, J. y Vila, A. (2013). "On the Extremes of Hunter-Fisher-Gatherers of America's Pacific Rim" Quaternary International, vol. 285, pp.1-10

Gusinde, M. (1937). Die Feuerland Indianer. 2 Band: Die Yamana. Mödling Bei Wien: Verlag der Internat. Zeitschrift Anthropos.

Hyades, P.D. y Deniker,J. (1891). Anthropologie et Ethnographie. Dins: Mission Scientifique du Cap Horn (1882-1883), vol.VII, París.

Piana, E. (1984). "Arrinconamiento o adaptación en Tierra del Fuego". Dins Ensayos de antropología argentina. Buenos Aires : Editorial de Belgrano, pp. 7-110.

Piana, E., Vila, A., Orquera, L. y Estévez. J. (1992). "Chronicles of Ona-Ashaga: Archaeology in the Beagle Channel". Antiquity vol. 66, n²52, pp. 771-783.

Vila, A. (2013). "Arqueología de 1800-1850: una mirada desde el otro lado de la frontera" Rev.Vínculos de Historia, no 2, pp. 287-308.

Vila, A. y Estévez, J. (2002). "Sociedades fueguinas: ¿desapariciones inevitables?" Dins: R. Piqué i M. Ventura (eds.) América Latina. Historia y Sociedad. Barcelona: ICCI y UAB, pp.107-118.

Vila, A. y Piana, E. (1993). "Arguments per a una etnoarqueologia. El projecte OnaAshaga". Revista d'Etnologia de Catalunya n03, pp. 151-154.

Vila, A., Estévez, J. y Romero, J.C. (prods.) (2006). Relaciones desenterradas. (Edición de Multimedia en DVD). AGAUR- GENERALITAT DE CATALUNYA. ISBN: 8489489-75-0 